\title{
BACK TO VIRTUE? \\ Some remarks on the reappraisal of virtue in ethics
}

\section{Robert Vosloo \\ University of the Western Cape}

\section{Abstract}

How is the recent reappraisal of virtue in ethics to be evaluated? The article examines this question. After mentioning a few possible reasons for the neglect of virtue in modern ethical theory, an attempt is made to chart something of the renewed interest in virtue in moral reasoning. This includes reference to the thought of Alasdair MacIntyre and Stanley Hauerwas. A plea is made that the recent reappraisal of virtue should be welcomed because it offers an important critique on certain ethical theories that deal with the moral life in static categories. It also offers the opportunity to rethink questions on moral formation anew - thus also giving resources for enriching moral discourse in South Africa. It is also argued, however, that a uncritical welcoming of virtue into (Christian) ethics can be irresponsible and that one needs to be reminded of certain pitfalls. In a brief final section it is also suggested that a constructive Christian ethic of virtue should have a Trinitarian base.

\section{The language of an ethics of being}

- In a letter published in the Afrikaans newspaper Die Burger on Human Rights Day (21 March 1996), the Afrikaans writer Hennie Aucamp argues that 'human rights' also imply 'human responsibilities' and 'human privileges'. The letter ends with the sigh that there will come a time when the name of Human Rights Day (Menseregtedag) will be changed to Right Humans Day (Regtemensedag).

- In the public discourse you often hear politicians and community leaders making statements such as: 'We have a new South Africa, now we need new South Africans.'

- In his doctoral dissertation Discipleship as Transformation? Towards a Theology of Transformation Russel Botman, with reference to Bonhoeffer's view on discipleship as transformitas Christi, argues that within the South African context there is a need, not only for mere reconstruction by means of programmes, but for transformation as a result of discipleship.

In my opinion the above mentioned utterances have this in common: they all suggest in some way or another that the so-called new South Africa should not only be about 'good' laws, rules and rights, but also about 'good' (or faithful) people - people who embody certain values and virtues. Laws and rules are indeed made, maintained and broken by people. It is difficult to determine whether these utterances are representative of the general public and church discourse, but they do bear an interesting resemblance to a definite shift in emphasis that has become discernible over the last few years in philosophical and theological ethics. There has been a movement away from a so-called ethics of doing (with the emphasis on the actions of the moral agent) towards an ethics of being (with the emphasis on the acting agent $)^{1}$. According to the ethics of being the important ethical question is not in the first

1 Naturally this shift in emphasis is closely correlated with the changing of the cultural situation and mirrors something of the shift from a modem to a so-called postmodem or late modern situation. Uncritically contraposing the ethics of doing with the ethics of being (or an ethics of duty with an ethics of virtue) can be dangerous in the description of the shift in emphasis in ethics. Nevertheless, the terms 'being' and 'doing' express something of the essence of the observable move in current ethical discourse. 
instance, 'What should I/we do? but, 'Who am Vare we?' or 'Who should I/we be?' It is thus conceded that actions are based on being (agere sequiter esse).

In ethical literature there has been increased emphasis on the fact that ethics is not only about rules and principles that guide the moral agent in complex decision-making situations. The character, virtues, visions, intentions and passions of the acting person, as well as the communities and institutions that surround him or her, also require thorough ethical scrutiny. In the light of the shift from an ethics of doing to an ethics of being, it can be expected that a connection will be made with the age-old tradition that links morality to a virtuous life. Currently one can rightly speak of a reappraisal of virtue in moral thinking. This brings rise to a question: How should this reappraisal of the virtues in ethics be understood and evaluated and what are the implications for the ethical discourse in South Africa? This article theologically investigates this question.

\section{The neglect of virtue in modern ethical theory}

Before referring to the recent reappraisal of virtue in ethics, it is important to note that for the better part of this century - with very few exceptions ${ }^{2}$ - positive discussions on virtue in literature on philosophical and theological ethics were few. Although contemplation on virtue and the virtues has a rich history in a variety of moral traditions ${ }^{3}$, one can rightly speak of an evasion of, or even a contempt for, the virtues within the modern ethical discourse.

One of the reasons for the fact that the virtues have not been given their rightful place in modern ethical theories, probably coheres with the methodological assumptions of the Enlightenment-formed ethical paradigm. It is characteristic of this paradigm that universal, ahistorical and rational considerations are applied to pass objective moral judgement. Religion poses a threat to this process because of its emphasis on historicity and particularity; therefore religion and morality have been kept apart. By demanding consideration of the virtues, attention is also focussed on the moral agent, thus accommodating the particularities of the moral agent (or of the community to which the person belongs) to contaminate the moral judgment with subjectivity. Therefore the 'objective' categories, such as obligations and norms have enjoyed priority over 'subjective' categories such as virtues. An ethics of obligation - as inspired by Immanuel Kant - can therefore be considered to be the dominant ethical paradigm of modernism. In situations where attention had been given to the virtues,

2 Here one thinks for example of the comprehensive work on the virtues of the Catholic philosopher, Josef Pieper. Compare e.g. his The Four Cardinal Virtues (1966 - this work originally appeared as separate essays in German and English between 1954 and 1959). For a discussion of Pieper's thoughts, see Meilaender 1984: 1-44. Romano Guardini, another Catholic philosopher's book The Virtues: On Forms of Moral Life (1967) can also be mentioned. As far back as 1915, however, an article Zur Rehabilitierung der Tugend of a German philosopher, Max Scheler, was published. In this article he shows the unpopularity of the word 'virtue' and pleads for virtuousness. Scheler points out that: 'diese alte, keifende, zahnlose Jungfer zu anderen Zeiten, z. B. in der Blute des Mittelalters und bei den Hellenen und Römern vor der Kaiserzeit, ein höchst anmutiges, anlockendes und charmevolles Wesen [waren]' (1955:15). Also compare G. Brillenburg Wurth's book Eerherstel van de deugd (1958) for a plea for the restoration
of virtue.

3 Compare for example Herms (1982); Crossin (1985) and Pesch (Mieth and Pohier 1987). For a short description of a number of important episodes in the (Western) tradition of thought concerning the virtuous life, see my article 'Etiek en die deugde: ' $n$ kritiese ondersoek na aanleiding van die herwaardering van die deugde in morele besinning' (1995). There are amongst others references to Plato, Aristotle, Augustine, Aquinas and Schleiermacher's descriptions of virtue. Although there are mainly recollections of episodes from the Western moral tradition, a lot can be learnt from other moral traditions about the virtuous life. In his book The Spirituality of
African Peoples: The Search for a Common Moral Discourse (1995) Peter Paris uses virtue language to explicate an African and African American social ethic. He makes it clear, however, that '(T)he basis of this ethics in the common worldview of African and African American peoples seperates it significantly from other traditions of virtue ethics that draw their source material from different cultural situations in order to address the moral issues implicit in those contexts' (1995:133). 
they were seen as sources from which obligations could be distilled and not as dinamic aspects of the moral life.

Another reason for the evasion of virtue coheres with the negative feeling that the word often evokes in present-day people. The word virtue recalls a petty bourgeoisie and Victorian moral stuffiness ${ }^{4}$. The virtuous are often depicted in the media and art as uninteresting and boring, whereas those embodying certain vices are depicted as colourful and passionate. Furthermore the idea of virtuousness suggests a moral hierarchy that clashes with the egalitarian suppositions of modern ethical and political theory.

Another important reason for the evasion of the virtues in especially Protestant ethics coheres with the interpretation of accents of the Reformation. It is feared that emphasis on the virtues will lead to an unhealthy emphasis on the subject that can easily turn into perfectionism or work righteousness ${ }^{5}$. In this process the danger arises that the grace of God can be understated. It is also feared that faith will be reduced to a kind of moralism and that the essence of the gospel will be misunderstood as a result. The gospel is not about 'good' people, but rather about 'new' people - people that have been redeemed by Christ. As the Protestant theologian Emil Brunner puts it in his book The Divine Imperative:

'The subject of a Christian ethic is neither birth nor race, nor a habit which has become a custom ('inherited nobility') nor is it even 'the Christian character,' but it is the new person, which, as such, is always something given and demanded' (1937:163).

And further:

Behind the present day revulsion from the 'virtuous man' - often decorated with all kinds of 'orders' for his virtuous conduct - lies the feeling that there is something wrong in this virtue which man has so to speak 'created,' that all this talk of 'possessing virtues' and of 'being virtuous,' indeed even the striving after such virtues, and even the mere ideal of virtue, is presumptuous. The idea of virtue leads man to justify himself - and this is the very opposite of all genuine goodness' (1937:165). ${ }^{6}$

It can also be argued that the reasons for the mistrust in an ethics of virtue cohere not only with the views adopted by the Enlightenment or liberal Western culture or the Reformation, but that it goes further back. In essence it has to do with the difference between Greek and

4 The feeling that the word 'virtue' evokes, is well summarised by Phaedrus, the main character in Robert M Pirsig's thought-provoking novel Lila: An Inquiry into Morals: 'He remembered elderly Victorians who had been nice to him as a child. It was a niceness that set him on edge. They were trying to improve him. It was expected that he would benefit from their attention. The Victorians always took themselves seriously, and the thing they took most seriously of all was their code of morality, or 'virtue', as they liked to call it' (1991:117).

For many the idea of virtuousness suggests the moral pride that Nietzsche strongly criticises when he writes: 'They want to scratch out the eyes of their enemies with their virtue; and they raise themselves in order to lower others' (1969:119). See also M Versfeld 1972:94.

5 Meilaender describes the possible dangers of an uncritical ethics of virtue well when he writes: 'Some day, when a historian writes a history of twentieth-century America, perhaps he or she will note that the turn in ethics to a concentration upon self, development of the self's character and vision, and the turn to an emphasis on being rather that doing, were not unexpected turns in an increasingly narcissistic age' (1984:13). Pesch (Mieth and Pohier 1987:92-93) summarises the Protestant complaints against virtue in a helpful manner:

(i) Virtue understood as habit turns life in the faith into a matter of practice. (ii) Man no longer needs God's grace as such but only to support his or her natural powers. (iii) The very nature of the concept forces the doctrine of virtue and habit to understand God's grace as a possession (albeit one that is bestowed on people), as something people 'have'. (iv) As a result the doctrine misunderstands the personal character of salvation. ( $v$ ) The doctrine also misunderstands the persistent reality of sin, since its starting-point is that sin has been swept aside.' Pesch also gives some interesting counter-criticism in this regard $(1987: 93,94)$.

6 In spite of Brunner's criticism against the assumptions of the classical teaching of virtue, he does point out that: 'Good, in the radical sense, does not mean 'doing good' but 'being good' (1937:163). He then leaves space, albeit in a qualified way, for virtue and character in ethics (compare 1937:168, 169). 
Christian views on mankind and the world. Naturally there are certain similarities between the views of the early church and the ancient culture in which it was embedded, but there is still an essential difference between Greek and Christian anthropology and cosmology. One can therefore expect some Christians to be sceptical about the Greek philosophical roots of the tradition of virtue. As Pieper (1966:xi) puts it:

'It is true that the classic origins of the doctrine of virtue later made Christian critics suspicious of it. They warily regarded it as too philosophical and not Scriptural enough. Thus, they preferred to talk about commandments and duties rather than about virtues' (also compare Schneewind 1990: 44, 45).

'In the light of the above mentioned reasons the question could be asked if it would not be better to ban the concept of virtue from moral thinking, especially from Christian moral thinking, all together. It is therefore understandable that ethicists (also Christian ethicists) rather focussed their attention on the creation of an ethics of rules or obligations (that apparently have more relevance to the Christian moral vision). Be that as it may, for the last few years the suppositions of a rigid ethics of obligation have increasingly been questioned. Their discontentment with the reductionist character of modern ethical and political theories caused ethicists to revisit the philosophies of Aristotle, Aquinas and the tradition of virtue. In a new introduction to his book Character and the Christian Life Stanley Hauerwas puts it as follows:

'For in effect the paradigm of ethics inherited from Kant has been burdened by so many anomalies, has died the death of so many qualifications, that a new alternative simply needed to be suggested' (1986: xiv).

For some ethicists the alternative means a search in the direction of a kind of revised form of an Aristotelian ethics of virtue. Other ethicists search in different directions. Although those in favour of an ethics of virtue (or ethics of being) agree on the fact that morality does not only have to do with that which one sometimes does, but rather with that which one is, it is clear that they have widely different views when they put their constructive suggestions on the table.

\section{The reappraisal of virtue in recent ethical discourse}

In the recent reappraisal of virtue in ethics the influential and much-discussed book After Virtue (1981, second edition 1984) of the moral philosopher Alasdair MacIntyre played a very prominent part. In this book MacIntyre argues that the modern person has to a great extent lost his or her conception of morality. All that we have are fragments of previous coherent moral traditions:

'... (A)ll those various concepts which informs our moral discourse were originally at home in larger totalities of theories and practice in which they enjoyed a role and function supplied by contexts of which they have now been deprived' (1984:10).

For MacIntyre this explains the lack of moral consensus about fundamental moral issues. In spite of the rationalistic pretences of the modern ethical project, it is a disguised form of emotivism according to MacIntyre ${ }^{7}$. For MacIntyre this is evident if you look at the central 'characters' of modern society, namely the bureaucratic manager, the rich aesthete and the

7 Maclntyre describes emotivism as follows: 'Emotivism is the doctrine that all evaluative judgments and more specifically all moral judgments are nothing but expressions of preference, expressions of attitude or feeling, insofar as they are moral or evaluative in character' $(1984: 11,12)$. 
therapist. $^{8}$

It is MacIntyre's contention that the modern moral crisis coheres with the (failed) project of the Enlightenment to base morality on rationality qua rationality. The ethical project of the Enlightenment rejects the classical view on the teleological nature of human existence - this is the reason why, according to MacIntyre, the Enlightenment project had to fail. The only hope in the current situation of moral chaos is turning back towards a (revised) Aristotelian ethics of virtue of some kind or another. A substantial part of After Virtue is therefore devoted to an insightful and nuanced discussion of the part virtue played in heroic societies, classical Athens, with Aristotle, as well as the Medieval contribution to the tradition of virtue. MacIntyre emphasises strongly that the virtues should be understood within the narrative context of an entire human life, as well as within the narrative context of a community and a tradition. Thus the category of 'narrative' plays an important role in MacIntyre's thought.

At the end of After Virtue it becomes clear that MacIntyre considers small communities as the settings for the virtuous life. Although he warns against comparing one epoch with another, he draws a comparison between the culture situation (in especially Europe and North America) in the last part of the twentieth century and the epoch during which the Roman empire started crumbling. MacIntyre ends the book with the suggestion that the tradition of virtue offers hope for the new dark ages of moral fragmentation and confusion that lies ahead. In his own words:

'What matters at this stage is the construction of local forms of community within which civility and the intellectual and moral life can be sustained through the new dark ages that is already upon us. And if the tradition of the virtues was able to survive the horrors of the last dark ages, we are not entirely without hope ... We are waiting not for Godot, but for another doubtless very different - St. Benedict' (1984:263).

In theological ethics the American theologian Stanley Hauerwas in a similar manner critices the moral presumpsions of the Enlightenment according to which morality is based on rationality qua rationality. According to Hauerwas moral judgments cannot be separated from the character, visions and virtues (in short, the story or narrative) of the moral agent. He therefore strongly emphasises these categories in his moral project. Although he does not deny the importance of rules and obligations, he is sceptical about an ethics that gives a central place to rules and obligations:

'Integrity, not obligation, is the hallmark of the moral life' (1977:41).

And:

'Prior to the kind of choices we make is the question of the kind of person we should be. Therefore, virtue is prior to decision, character to choice' (1988:70).

Hauerwas strongly emphasises the fact that virtues, like skills, are acquired through practice within communities. Whereas MacIntyre emphasises the polis as locus of moral formation, Hauerwas emphasises the ekklesia. For Hauerwas Christian communities, shaped by the true stories of Israel and Jesus, are the true schooling environments for the virtues. In his later work Hauerwas distances himself from a plea for virtue in general and points out that Christian virtue should not be equated with certain Greek and liberal virtues in an uncritical manner. ${ }^{9}$

8 For MacIntyre 'the character' morally legitimates a mode of social existence. He writes: 'They are, so to speak, the moral representatives of their culture and they are so because of the way in which moral and metaphysical ideas and theories assume through them an embodied existence in the social world. Characters are the masks worn by moral philosophies' (1984:28).

9 See for example his article 'The Difference of Virtue and the Difference It Makes: Courage Exemplified' (1993). His ideas on character and virtue are scattered throughout his work, see especially Vision and Virtue (1974); 
Although MacIntyre and Hauerwas are probably the most prominent exponents of the new interest in an ethics of virtue, it is by no way only restricted to them. The basic thoughts on an ethics of virtue are found on a wide variety of territories. Over the last few years literature on the virtues have appeared in philosophical ethics ${ }^{10}$, theology ${ }^{11}$, applied ethics ${ }^{12}$ and cultural studies $^{13}$. Although the named literature in the above mentioned foot notes is sketchy, it still gives one a good idea of the wide spread interest in the virtues. A few years ago Yearley

Character and the Christian Life $(1975,1986)$ and A Community of Character (1981). For a discussion on Hauerwas's ethical project, see Richardson's article in Villa-Vicencio and De Gruchy (eds) (1994), as well as my doctoral thesis 'Verhaal en Moraal: 'n Ondersoek na die narratiewe etiek van Stanley Hauerwas' (1994).

10 A lot of the renewed interest in the virtues in philosophical ethics can be traced back to the classic article of Elisabeth Anscombe 'Modem Moral Philosophy' (1958). In this article she argues that the concepts 'moral duty', 'morally right and wrong' and 'morally ought' are remnants of an earlier conceived framework that cannot be maintained any longer. This is only possible from a theistic religious context. When out of context (like a modern moral philosophy), these concepts loose their coherence. Anscombe suggests that the reconstruction of Aristotle's ethics may be the only way out of this impasse. The virtues naturally play an important role in this regard. The influence of Anscombe is observed in the thought of MacIntyre. Over the last few years there have been a number of comprehensive studies on Aristotle's view on the good life and the virtues. Compare e.g. Martha C Nussbaum, The Fragility of Goodness: Luck and Ethics in Greek Tragedy and Philosophy (1986) and Love's Knowledge: Essays on Philosophy and Literature (1990); A O Rorty (ed), Essays on Aristotle's Ethics (1980); N Sherman, The Fabric of Character: Aristotle's Theory of Virtue (1989); S Broadie, Ethics with Aristotle (1991) and J Annas, The Morality of Happiness (1993).

There has also been an increasing number of discussions in periodicals and books on, for example, the role of virtue in the moral views of some thinkers, the relation between an ethics of virtue and other moral theories (such as Kantianism or Utilitarianism) and the role of the passions in an ethics of virtue. Beside the work of MacIntyre concerning the virtues, amongst the profusion of philosophical literature, there can be referred to: $\mathrm{P}$ Geach, The Virtues (1977); P Foot, Virtues and Vices and Other Essays in Moral Philosophy (1977); J Wallace, Virtues and Vices (1978); M Slote, Goods and Virtues (1984) and From Morality to Virtue (1992); E Pincoff, Quandaries and Virtues (1986); Kruschwitz and Roberts (eds), The Virtues: Contemporary Essays on Moral Character (1987); P French, T Uehling and H Wettstein (eds), Ethical Theory: Character and Virtue (1988); J J Kupperman, Character (1991); R Poole, Morality and Modernity (1991); J W Chapman and W A Galston (eds), Virtue (1992).

11 There has already been referred to the influential ideas of Stanley Hauerwas that character and virtue have a certain preference above obligation and choice. These accents are, however, already present in the earlier work of another influential American ethicist, James Gustafson (see for example his book, Can Ethics be Christian? - 1975). However, Gustafson and Hauerwas's ethical projects have developed into different directions. Whereas Hauerwas emphasises the importance of the Christian community, the pathos of Gustafson's (later) ethics tends in the direction of interaction with the wider, secular culture.

Within theology there are a growing amount of literature that, like Hauerwas, investigate the importance of character, the virtues, narrative, community and other such categories for the moral life. E.g. G C Meilaender, The Theory and Practice of Virtue (1984); J W Crossin, What Are They Saying About Virtue? (1985); J W McClendon, Systematic Theology: Ethics (1986); R J Neuhaus (ed), Virtue - Public \& Private (1986); D Mieth and J Pohier (eds), Changing Values and Virtues (1987); L B Smedes, A Pretty Good Person (1990); R J Mouw, Uncommon Decency (1992); P Kreeft, Back to Virtue (1992); J Porter, The Recovery of Virtue: The Relevance of Aquinas for Christian Virtue (1990); G S Harak, Virtuous Passions: The Formation of Christian Character (1993); B W Farley, In Praise of Virtue: An Exploration of the Biblical Virtues in Christian Context (1995). See also the review articles of Yearley (1990) and Spohn (1992). For discussions on virtue in the German Language, see D Mieth, Die neue Tugenden (1984) and K Stock, Grundlegung der protestantischen Tugendlehre (1995).

Within theology there is a group of practical theologians that link ideas about the virtues to work done in the fields of developmental psychology and moral education. Compare C Dykstra. Vision and Character (1981) and D Capps, Deadly Sins and Saving Virtues (1987).

12 Increasingly one finds applied ethical studies where the categories of character and virtue are used. This is apparent when one considers the titles of a few books which appeared recently, e.g. J F Drane, Becoming a Good Doctor: The Place of Virtue and Character in Medical Ethics (1988, 1995 - second edition) and O F Williams and J W Houck (eds), A Virtuous Life in Business: Stories of Courage and Integrity in the Corporate World (1992).

$13 \mathrm{n}$ culture critical studies there is often referred to the role of the virtues in the broader dialogue about moral development within liberal, secularised and democratic societies such as the USA. E.g. B Darling-Smith (ed), Can Virtue Be Taught? (1993); M A Glendon and D Blankenhorn (eds), Seedbeds of Virtue: Sources of Competence, Character, and Citizenship in American Society (1995). The Book of Virtues (1993), William Bennet's best-seller book with moral literacy as its aim, can also be mentioned. 
rightly said about the reappraisal of virtue:

'A fashionable opening, for a time, to reviews of works on virtue was to note and often bemoan the neglect of the topic. That rhetorical gambit can no longer be used; indeed, what only ten years ago was a cottage industry threatens to become an industrial giant' (1990:1).

In the beginning of this article it has been suggested that in the South African context too the language of an ethics of being is increasingly being spoken. This compels one anew to evaluate the recent reappraisal of the virtues.

\section{Back to virtue? Yes!}

How should the recent reappraisal of the virtues be evaluated? Naturally the different philosophers' thoughts should be judged individually, but it is nevertheless possible to make a few general positive comments on the reappraisal of virtue in ethical discourse.

a. An ethics of virtue (or ethics of being) rightly is critical of a rigid ethics of obligation that deals with the moral life in static categories. By emphasising the character and virtues of the moral agent, a stand is made against any effort to reduce moral life to merely making choices in complex situations. Choices and decisions are not unimportant, but morality has more to do with the character, vision and virtues of the acting agent than with the making of difficult decisions in the light of deontological and teleological norms in situations that have been abstracted from their narrative context. Morality indeed has to do not only with the things that one (sometimes) does, but with identity as well.

Another danger that exists is that an uncritical alliance with a Kantian ethics of duty can lead to the fact that even in Protestant ethics, which emphasises the role of the conscience, the moral life is reflected on in terms of static categories. A responsible reflection on issues such as character, vision and virtue offers the opportunity to oppose the setting of moral life into rules and obligations and thus to do justice to the dinamics of the Christian life.

b. The accents of an ethics of virtue offers the opportunity to reflect on moral (trans)formation anew. How are values and virtues formed? How are they changed? Even more fundamental, the age-old question of Socrates: Can virtue be taught? These questions are currently central in the debate about the so-called morality crisis in South Africa. An ethics of being offers valuable perspectives for the debate on morality in South Africa in that it helps us to understand that the morality crisis is actually an identity crisis.

The accents of an ethics of virtue with respect to stories, imagination, role models (heroes and saints), social practices (e.g. friendships), etc. in the process of moral formation furthermore offer a wealth of insights that may be exploited and thus enriching ethical discourse.

Because an ethics of being not only frees our moral imaginations from the presumptions of modern ethical theories, but also questions the presumptions of modern political theories, it also poses questions to the role of particular (religious) communities and institutions in the process of moral formation. Christians often emphasise the role of religious communities in the process of moral transformation. However, it remains essential that Christians continually ask themselves how these religious communities are doing in the process of moral formation. And further: How should the moral influence of certain institutions, films and literature be judged theologically?

The emphasis on moral formation might sound strange to the Kantian conditioned ear, 
but maybe it is good to recall Larry Rasmussen's argument that Kant and company assumed an ethics of character and virtue, but that it never became evident in their theories. He writes in his book Moral Fragments and Moral Community:

'Perhaps Kant, Bentham and company simply forgot that we are children before we are adults and that the moral life does not begin in 'reason' but in childhood!' (1993:74).

One wonders if Protestants need not to be reminded that Luther too was a child once! ${ }^{14}$

c. The emphasis on virtue in ethics also offers the opportunity to contemplate specific virtues anew. The responsible contemplation of virtues such as non-violence, hospitality, courage, patience, etc. may fill a prominent gap in ethical thought.

\section{Back to virtue? Yes, but ...}

It is true that the recent reappraisal of virtue in ethics rightly draws attention to issues that have been neglected in modern ethical thought. However, one should be aware that an uncritical welcoming of virtue in (Christian) ethics can be dangerous.

a. The danger exists that a general plea for an ethics of virtue may not neccesarily be sinonymous with a plea for Christian virtue/ virtues. In his later work, Hauerwas strongly warns against this. Although he himself is critical of modern ethical theories and emphasises issues such as character and virtue in his ethical project, he is of opinion that it is dangerous to give relevancy to certain communities by arguing that they can serve public life by being virtuous communities. In Hauerwas's words:

'... (S)uch a celebration of virtue fails to acknowledge the difference between virtue theories and the difference that such difference makes. Moreover that difference is political since different polities will produce different accounts of virtue ... (A)11 accounts of virtue are not created equally' (1993:251).

Hauerwas (1993:249-264) illustrates this thought with reference to the virtue of courage. Hauerwas is of opinion that the exemplary illustration of courage, namely that of soldiers in battle, should not be normative for Christians. Christians should always be wary of illustrations of courage that derive their intelligibility from war. For Christians martyrdom is a more exemplary illustration of courage. John Milbank also warns in his book Theology and Social Theory (1990:326-379) that there is a difference between Greek arete and Christian caritas. According to Milbank the former is based on a politics of


peace. ${ }^{15}$

Side by side with the fact that there should be guarded against the confusing of Christian virtue with Greek virtue, the danger also exists of linking or separating Christian

14 aturally it is important that moral formation has a specific meaning for Christians. As Bonhoeffer puts it: (F)ormation comes only by being drawn into the form of Jesus Christ. It only comes as formation in his likeness, as conformation with the unique form of Him who was made man, was crucified, and rose again' (1955:61).

15 he idea that there is a fundamental difference between Greek and Christian virtuousness is also articulated by Paul Ramsey when he remarks that '... the Christian ideal of character is not the same as the Greek, 'In nothing too much, and something of everything'; Aristotle's ethic of the 'mean' is not the same as Jesus' 'ethic of the extreme" (1950:194). In his book Pagan Virtue: An Essay in Ethics John Casey reflects on the cardinal virtues. He also underlines the differences between 'pagan virtue' and what he calls an 'ethic of persons' which owes a lot to the Christian tradition. 
virtues in an uncritical manner with or from certain liberal virtues (e.g. tolerance, freedom of speech and religion, etc.). The same goes for certain concervative cultural values. The plea for virtue can easily become a form of nostalgia that shrinks back from the concrete responsibilities that are required by the present.

b. A further danger that threatens when the virtues are integrated in ethics, is that the virtues are used supplementary to an ethics of norm, leaving the presumptions of modern epistemology untouched. Thus the plea for virtue becomes similar to the Romantic reaction to the Enlightenment. In effect it leads to the banning of virtue to the private sphere, whereas participation in the public sphere requires 'objective' norms and obligations. Subsequently the object-subject scheme of the Enlightenment with all its negative results is sustained.

c. Although one can argue that the plea for virtue does not necessarily oppose the grace of God, the reluctance of the Reformation to use virtue as a moral category is a reminder that the plea for virtue should not become a new law. The pending danger of moralism indeed threatens an ethics of virtue.

The intention of the criticism of the Enlightenment with regard to virtue should also be kept in mind continuously. Whenever the plea for virtuousness is discussed, it is not long before questions such as: Which virtues? and Whose virtues? are posed. And also: Who determines the criteria according to which some virtues are recommended and others are disapproved of? These questions should not be dismissed too easily; they indicate the importance of providing reasons for one's actions and preferences in order to oppose ethical arbitrariness. Regarding these questions seriously does not imply acquiescence with regard to the rationalistic and universal presuppositions of the modern ethical paradigm.

The plea for an ethics of virtue can easily turn into a new form of dictatorship that leads to violence. The postmodern criticism against such totalitarianism serves as important resistance. In my opinion it is important to utilise certain resistance devices within the Christian tradition to resist the possible tiranny of virtuousness.

To conclude: in the space that the plea for virtue has created for Christian ethical contemplation it is important that a responsible Christian ethics will have sensitivity for the fact:

- that the plea for virtue can easily be a camouflaged form of petty bourgeoisie. It might be a good thing for Christians to constantly remind themselves of Nietzsche's advice:

'And even when one has all the virtues, there is still one thing to remember: to send even these virtues to sleep at the proper time' (1969:56).

- that the plea for virtue can easily turn into a new law

- that the plea for virtue can lead to a new arbitrariness

- that the plea for virtue can turn into a new dictatorship

- that the virtues that are pleaded for should not be equated to Christian virtues in an uncritical manner.

\section{A further important question}

In the beginning of this article there has been referred to a shift of emphasis from an ethics of doing to an ethics of being, or from the question: What should $\mathrm{V} / \mathrm{we}$ do? to: What should $\mathrm{I} / \mathrm{we}$ be? The shift from the question on good behaviour to the question on the good person or the good community, offers the opportunity to ethically contemplate the identity of the moral 
agent (and the identities of communities and institutions that surround a person). Something, however, that is often lacking with those in favour of a Christian ethics of virtue is a methodological consideration of a further question, namely: 'Whose are we/am I?' (or 'For whom are we/am I?'). Or put differently: The 'being' in an ethics of being is not always a 'being in God'. Thus the plea for virtuousness is not always based pneumatologically. A Christian ethics of virtue should more strongly have a trinitarian base than is often the case. ${ }^{16}$ The further development of this emphasis seems to me imperative for a constructive and responsible Christian ethics of virtue (or being).

In the current debate in South Africa about morality, values and virtues there can be learnt a lot from the recent reappraisal of virtue in ethics. The debate (the Christian ethical debate also) within the South African context can be enriched by taking note - as indicated above - of the good points as well as the dangerous areas.

\section{BIBLIOGRAPHY}

Annas, J 1993. The Morality of Happiness. New York: Oxford University Press.

Anscombe, G E M 1958. Modern Moral Philosophy. Philosophy 33.

Bennett, W J 1993. The Book of Virtues. New York: Simon \& Schuster.

Bonhoeffer, D 1955. Ethics. Londom: SCM Press.

Botman, H R 1993. 'Discipleship as Transformation? Towards a Theology of Transformation'. Ongepubliseerde proefskrif, Universiteit van Wes-Kaapland.

Brillenburg Wurth, G 1958. Eerherstel van de deugd. Kampen: Kok.

Broadie, S 1991. Ethics with Aristotle. New York: Oxford University Press.

Brunner, E 1937. The Divine Imperative: A Study in Christian Ethics. London: Lutterworth Press.

Capps, D 1987. Deadly Sins and Saving Virtue. Philadelphia: Fortress Press.

Casey, J 1990. Pagan Virtue: An Essay in Ethics. Oxford: Clarendon Press.

Chapman, J W; Galston, W A (eds) 1992. Virtue. NOMOS XXXIV. New York: New York University Press.

Crossin, J W 1985. What Are They Saying About Virtue? New York: Paulist Press.

Darling-Smith, B (ed) (1993). Can Virtue Be Taught? Notre Dame: University of Notre Dame Press.

Drane, J F 1995. Becoming a Good Doctor: The Place of Virtue and Character in Medical Ethics (second edition). Kansas City, MO: Sheed \& Ward.

Dykstra, C 1981. Vision and Character. New York: Paulist Press.

Farley, B W: In Praise of Virtue: An Exploration of the Biblical Virtues in Christian Context. Grand Rapids: Eerdmans.

Foot, P 1978. Virtues and Vices and Other Essays in Moral Philosophy. Oxford, England: Blackwell.

French, P; Uehling, T, Wettstein, H (eds) 1988. Ethical Theory: Character and Virtue. The

16 he work of L G Jones offers valuable suggestions in this regard. See his book Transformed Judgment: Towards a Trinitarian Account of the Moral Life (1990) and his more specific study Embodying Forgiveness: A Theological Analysis (1995). Konrad Stock's proposal (1995) for a Protestant virtue ethics also have a trinitarian structure. 
Midwest Studies in Philosophy. Notre Dame: University of Notre Dame Press. Geach, P 1977. The Virtues. Cambridge, England: University of Cambridge Press.

Glendon, M A and Blankenhorn, D (eds) 1995. Seedbeds of Virtue: Sources of Competence, Character, and Citizenship in American Society. London: Madison Books.

Guardini, R 1967. The Virtues: On Forms of Moral Life. Chicago: Henry Regnery. Gustafson, J M 1975. Can Ethics be Christian? Chicago: University of Chicago Press.

Harak, G S 1993. Virtuous Passions: The Formation of Christian Character. New York: Paulist Press.

Hauerwas S, 1974. Vision and Virtue: Essays in Christian Ethical Reflection. Notre Dame: Fides Publishers.

Hauerwas, S 1977. Truthfulness and Tragedy: Further Investigations into Christian Ethics. Notre Dame: University of Notre Dame Press.

Hauerwas, S 1981. A Community of Character. Notre Dame: University of Notre Dame Press.

Hauerwas, S 1986. Character and the Christian Life. San Antonio: Trinity University Press.

Hauerwas, S 1988. Christian Existence Today: Essays on Church, World, and Living In Between. Durham, North Carolina: The Labyrinth Press.

Hauerwas, S 1993. The Difference of Virtue and the Difference it Makes: Courage Exemplified. Modern Theology 9/3: 249-264.

Herms, E 1982: Virtue: A Neglected Concept in Protestant Ethics. Scottish Journal of Theology. 35: 481-495.

Jones L G 1990. Transformed Judgment: Towards a Trinitarian Account of the Moral Life. Notre Dame: University of Notre Dame Press.

Jones, L G 1995. Embodying Forgiveness: A Theological Analysis. Grand Rapids: Eerdmans.

Kreeft, P 1992. Back to Virtue. San Francisco: Ignatius Press.

Kruschwitz, R B; Roberts, R C (eds) 1987: The Virtues: Contemporary Essays on Moral Character. Belmont, California: Wadsworth.

Kuppelman, J J 1991. Character. New York: Oxford University Press.

MacIntyre, A 1984. After Virtue. Notre Dame: University of Notre Dame Press (second edition).

McClendon, J W 1986. Systematic Theology: Ethics. Nashville: Abingdon Press.

Meilaender, G C 1984. The Theory and Practice of Virtue. Notre Dame: University of Notre Dame Press.

Mieth, D 1984. Die neue Tugenden: Ein ethischer Entwurf. Düsseldorf: Patmos-Verlag.

Mieth, D; Pohier, J (eds) 1987. Changing Values and Virtues (Concilium). Edinburgh: T \& T Clark Ltd.

Milbank, J 1990. Theology and Social Theory: Beyond Secular Reason. Oxford: Blackwell.

Mouw, R J 1992. Uncommon Decency: Christian Civility in an Uncivil World. Downers Grove, Illinois: Intervarsity Press.

Nussbaum, M C 1986. The Fragility of Goodness. Luck and Ethics in Greek Tragedy and Philosophy. Cambridge: Cambridge University Press.

Nussbaum, M C 1990. Love's Knowledge: Essays on Philosophy and Literature. New York: Oxford University Press. 
Neuhaus, R J (ed) 1986. Virtue - Public \& Private (Encounter Series). Grand Rapids: Eerdmans.

Nietzsche, F 1969. Thus Spoke Zarathustra. Harmondsworth, Middelsex: Penquin Books Ltd.

Paris, P J 1995. The Spirituality of African Peoples: The Search for a common Moral Discourse. Minneapolis: Fortress Press.

Pincoff, E 1986. Quandaries and Virtues: Against Reductionalism in Ethics. University Press of Kansas.

Pirsig, R M 1991. Lila: An Inquiry into Morals. London: Corgi Books.

Poole, R 1991. Morality and Modernity. London: Routledge.

Porter, J 1990: The Recovery of Virtue: The Relevance of Aquinas for Christian Ethics. Louisville: Westminster/ John Knox Press.

Pieper, Josef 1966. The Four Cardinal Virtues. Notre Dame: University of Notre Dame Press.

Ramsey, P 1950. Basic Christian Ethics. Chicago and London: The University of Chicago Press.

Rasmussen, L 1993. Moral Fragments \& Moral Community. Minneapolis: Fortress Press.

Rorty, A O (ed) 1980. Essays on Aristotle's Ethics. Berkeley: University of California Press.

Scheler, M 1955: Vom Umsturz der Werte: Abhandlungen und Aufsätze (Gesammelte Werke 3). Bern: Francke.

Schneewind, J B 1990. The Misfortunes of Virtue. Ethics 101: 42-63.

Sherman, N 1989. The Fabric of Character: Aristotle's Theory of Virtue. Oxford: Clarendon Press.

Slote, M 1984. Goods and Virtue. Oxford: Clarendon Press.

Slote, M 1992. From Morality to Virtue. New York: Oxford University Press.

Smedes, L B 1990. A Pretty Good Person. San Francisco: Harper \& Row.

Spohn, W C 1992. The Return of Virtue Ethics (Notes on Moral Theology): 1991). Theological Studies 53: 60-75.

Stock, K 1995. Grundlegung der protestantischen Tugendlehre. Gütersloh: Chr. Kaiser/ Gütersloher Verlagshaus.

Versfeld, M 1972. Persons. Cape Town: Buren Publishers Ltd.

Villa-Vicencio, C; De Gruchy, J (eds) (1994). Doing Ethics in Context: South African Perspectives. Maryknoll, New York: Orbis Books; Cape Town: David Philip.

Vosloo, R R 1994. 'Verhaal en Moraal: 'n Kritiese ondersoek na die narratiewe etiek van Stanley Hauerwas'. Ongepubliseerde D.Th-proefskrif, Universiteit van WesKaapland.

Vosloo, R R 1995. Etiek en die deugde: 'n kritiese ondersoek na aanleiding van die herwaardering van die deugde in morele besinning. NGTT 36/2: 272-283.

Wallace, J 1978: Virtues and Vices. Ithaca, New York: Cornell University Press.

Williams, O F and Houck, J W (eds) 1992. A Virtuous Life in Business: Stories of Courage and Integrity in the Corporate World. Landham, MD: Rowman \& Littlefield.

Yearley, L H 1990. Recent Work on Virtue. Religious Studies Review 16/1: 1-9. 